\title{
CLONING AND EXPRESSION OF CHEMOKINE RECEPTOR CXCR4 IN EUKARYOTIC CELLS CHO, HEK293 AND BHK21
}

\author{
Arnis Strods, Ramona Petrovska, Ludmila Jackeviča, and Regina Renhofa \\ Biomedical Research and Study Centre, Rātsupītes ielā 1, Rīgā, LV-1067, LATVIA; \\ E-mail: a.strods@biomed.lu.Iv \\ Communicated by Pauls Pumpēns
}

\begin{abstract}
Chemokines and their receptors are now under intensive investigation from different points of view: theoretically, to understand "how they work", and practically, to discover methods to affect or to force cellular processes into organisms in the intended direction. Evidence gathered during recent years suggests an important role for chemokines in normal cell proliferation, migration, intracellular communication, but what is of greater interest is their number of pathophysiological processes, such as chronic and acute inflammation, infection diseases, modulation of angiogenesis, tumour growth and spread. Chemokines have been also in several brain areas, where ligand-receptor systems can seriously alter the action of neuronally active pharmacological agents. Our interest is focused on the receptor/ligand pair CXCR4 / CXCL12 (SDF-1). We attempted the overexpression of this receptor into several eukaryotic cell lines for detailed interaction studies of receptor CXCR4 with ligands that were virus-like particles-based analogs of its only known natural ligand SDF-1 or stromal cell derived factor. This study evaluates the expression of CXCR4 into cells CHO, HEK293 and BHK21 with the idea of developing a handy "instrument" for further investigations.
\end{abstract}

Key words: CXCR4, SDF-1, chemokine receptor cloning, transfection.

\section{INTRODUCTION}

Chemokines have molecular masses of $8-10 \mathrm{kDa}$, show from 20 to $50 \%$ sequence homology at the protein level; different chemokines are structurally similar, having at least three $\beta$-sheets and $\mathrm{C}$-terminal $\alpha$-helix. According to the number and position of conserved cysteines involved in intramolecular disulphide bond formation they are classified into four subclasses: in two main groups $(\mathrm{CXC}, \mathrm{CC})$ and two minor groups $(\mathrm{C}, \mathrm{CX} 3 \mathrm{C})$. In the $\mathrm{CXC}$ group, two cysteines are separated by a single aminoacid (X), while, in $\mathrm{CC}$, the first two cysteines are adjacent. In the two minor groups there are chemokines with structural types $\mathrm{C}$ and CX3C (one cysteine; two cysteines separated by three amino acids). Chemokine receptors are G-protein-coupled and belong to a seven-transmembrane domain spanning a rodopsin-like receptor family.

Numerous data convincingly show the particular biological role and functional importance of the receptor/ligand pair CXCR4/CXCL12 (SDF-1). After designation of LESTR/ fusin receptor as a novel CXCR4 receptor (Bleul et al., 1996), its role as a co-receptor (together with CCR5) for HIV-1 entry into cells was estimated (Bleul et al., 1996; Nagasawa et al., 1999). This is the main reason why CXCR4 was chosen for therapeutic targeting, for example, see Fujii et al. (2003). CXCR4 is highly expressed in many types of tumours, especially in cases connected with metastasis formation. Many studies suggest that the mechanisms for homing of leukocytes and hematopoietic progenitors may be appropriate for the dissemination of tumours via the bloodstream and lymphatic system. CXCR4 is predominantly expressed on lymphocytes where it activates chemotaxis. CXCR4 is able to activate several phenomena such as chemotaxis, invasion, angiogenesis and proliferation (Schrader et al., 2002; Kato et al., 2003; Almofti et al., 2004; Darash-Yahana et al., 2004; Kalinkovich et al., 2006). High level CXCR4-tumours show more extensive nodal metastasis in comparison with low-expressing tumours (Kato et al., 2003); overexpression of CXCR4 in cancer specimens in most cases predicts a bed outcome for patients (Holm et al., 2007) and this is maybe the most important reason why receptor CXCR4 is a potential and very significant target for therapy (Murphy et al., 2005; Tsutsumi et al., 2007).

Recently, a new look at the brain endogenous chemokine system, consisting of ligands and receptors, and also of the pair of our choice CXCR4/SDF-1, allowed it to be named as the third major communication system in the brain alongside neurotransmitter (neuromodulator) and neuropeptide (neurohormone) systems (Adler et al., 2006). This obstacle also predicts receptor CXCR4 as a very important therapeutic target in the future.

The goal of the present work is to overexpress chemokine receptor CXCR4 into cells CHO, HEK293 and BHK21 in order to develop a system for further study of interactions between the receptor and its modified ligands. 


\section{MATERIALS AND METHODS}

Construction of plasmids. Two constructions were undertaken: plasmid pcDNA3-CXCR4, containing the CXCR4 protein expressing sequence, and plasmid pCEP4-CXCR4eGFP, containing the CXCR4 protein expressing sequence C-terminally prolonged with the eGFP coding sequence.

The CXCR4 sequence was cloned directly from purified human DNA (kindly donated by Dr. Liene N,ikitina-Zake), pretreated with $\mathrm{X} b a \mathrm{I}$ restriction endonuclease (all restriction endonucleases were obtained from Fermentas). When constructing pcDNA3-CXCR4 PCR the fragment was made by using primers pARS13 and pARS14 (pARS13, forward: 5'GGG AAG CTT GCT AGC ATG GAG GGG ATC AGT ATA TAC ACT TCA GAT AAC TAC ACC GAG GAA ATG -3', and pARS14, reverse: 5' - ACA CTC GAG TTA GCT GGA GTG AAA ACT TGA AGA CTC AGA -3') (supplied by Metabion). After digestion with HindIII and XhoI, the fragment was ligated into vector pcDNA3 (Invitrogen) under CMV promoter.

In the case of construction of pCEP4-CXCR4-eGFP, the fragment was cloned by PCR reaction applying primers pARS13 and pARS15 (pARS15, reverse: 5'- TCT CTC GAG GCT GGA GTG AAA ACT TGA AGA CTC AGA -3') (supplied by Metabion). After digestion with HindIII and $\mathrm{XhoI}$, the fragment was ligated into a modified version of Invitrogen's vector pCEP4 (kindly donated by Dāvids Frīdmanis) under CMV promoter, containing the eGFP sequence from vector pEGFP N1 (Clonetech).

Both plasmids were multiplied by transformation into $E$. coli RR1 cells. After subsequent purification with JetStar 2.0 (Genomed), cloned sequences were proofed by sequencing and subsequent comparison with human CXCR4 sequence (GenBank, \#AF005058).

Cells. The Chinese hamster ovary CHO (ATCC), human embryonic kidney HEK293 (ATCC), human hepatocellular carcinoma HepG2 (ATCC), rat hearth myoblast (H9c2) (ECACC) and Syrian hamster kidney fibroblast BHK21 (ATCC) cells were grown at $37^{\circ} \mathrm{C}, 5 \% \mathrm{CO}_{2}$, in Dulbecco's modified Eagle's medium (DMEM) (Invitrogen), supplemented with $10 \%$ foetal bovine serum (FBS) (Invitrogen), $100 \mathrm{U} / \mathrm{ml}$ penicillin and $0.1 \mathrm{mg} / \mathrm{ml}$ streptomycin (Sigma, P4333). To detach cells from the surface, $0.5 \mathrm{mg} / \mathrm{ml}$ trypsin (Sigma, T4549) and versen (0.14 M NaCl, $2.7 \mathrm{mM} \mathrm{KCl}, 8.1$ $\mathrm{mM} \mathrm{Na} \mathrm{HPO}_{4}, 1.5 \mathrm{mM} \mathrm{KH}{ }_{2} \mathrm{PO}_{4}, 0.7 \mathrm{mM}$ EDTA, pH 7.4) were used. For transfection or cell ELISA experiments, $1 \times$ $10^{6}$ cells were subcultured onto one $6 \mathrm{~cm}$ diameter Petri dish or 96-well plate, respectively.

Antibodies. Two kinds of anti-CXCR4 antibodies were used - monoclonal anti-human mouse antibodies to whole receptor molecule purchased from Sigma (clone 44716.111), and polyclonal rabbit antibodies, kindly prepared by Dr. Dace Skrastina, called anti-543; these antibodies were prepared using as antigen, himeric virus-like particles formed from bacteriophage coat protein fused with a thirty nine N-terminal aminoacid long fragment of the CXCR4 sequence (Crump et al., 1997). Peroxidase conjugates were diluted 5000 times for anti-mouse conjugate (Sigma, A4416) or 7000 times for anti-rabbit conjugate (Sigma, A6154) and Protein A (Sigma, P8651).

Transfection of eukaryotic cells. CHO, HEK293 and BHK21 cells at 50-70\% confluence were transfected with plasmid pCEP-CXCR4-eGFP into cells either via lipofectin-DNA globules (lipofectin was made according to Campbell, 1995) or by using TurboFect transfection reagent (Fermentas, \#R0531).

For transfection with lipofectin reagent, cells were washed with PBS (Sigma, P3813), incubated with previously prepared liposomes containing encapsulated DNA in OptiMEM medium (Invitrogen) and, after six hours, the medium was changed to DMEM containing 5\% FBS. Liposomes were made by mixing $40 \mu$ lipofectin reagent and $10 \mu \mathrm{g}$ of DNA, and by incubating 20 minutes at room temperature. Transfection events were confirmed by fluorescent inverted microscopy after continuous cell growth (24-72 hours); cells were washed with PBS and scraped off the growth surface. For microscopy, during the medium change step, cells were scraped off the growth surface and suspended and seeded onto 8-chamber glass microscopy slides. They were then allowed to attach to the surface for at least 12 hours at $37{ }^{\circ} \mathrm{C}, 5 \% \mathrm{CO}_{2}$.

Transfections of cells with Fermentas TurboFect reagent were mostly carried out according to manufacturer's recommendations. However, some modifications were undertaken. The transfection mixture from plasmid pCEP4CXCR4-eGFP and TurboFect was prepared according to the manufacturer's instructions, incubated 30 minutes at room temperature and then poured onto cells. In one case (method A) the reaction mixture was added directly to cells and the growth medium (DMEM containing 5\% FBS) added. In the second case (method B) reaction mixture was added directly in the growth medium, and after 24 hours growth, the medium was changed to a new one. As in the case of transfection with lipofectin, after transfection, the cells need to be grown 24 or 48 hours in the conditions described above. Only after that it is possible to detach them from the growth surface by scraping.

Cell ELISA. In this procedure the appropriate cells (both non-transfected and transfected) were seeded in equal amounts onto 96 -well plates $\left(10^{6}\right.$ cells per plate; counted using a counting chamber) and grown for 48 hours in DMEM containing 5\% FBS as described above. For stronger cell adhesion the 96-well plates were pretreated with poly-L-lysine (Sigma) $(0.005 \%)$ for $30 \mathrm{~min}$, washed three times with PBS and then thoroughly dried in air. The growth medium of ready pre-grown cells was exchanged for DMEM (without FBS) and the cells were incubated for 30 minutes. After incubation, the medium was removed and the cells were fixed with $3.7 \%$ formalin (diluted in PBS) for 5 minutes. Further procedures were as in standard ELISA: incubation with $1 \%$ BSA in PBS for an hour at $37^{\circ} \mathrm{C}$, incu- 
bation with primary antibodies (commercial mouse-CXCR4 antibodies or rabbit-543 antibodies) for an hour at $37^{\circ} \mathrm{C}$, incubation with $1 \% \mathrm{BSA}$ in $\mathrm{PBS}$ for $15 \mathrm{~min}$ at $37^{\circ} \mathrm{C}$, incubation with secondary antibodies (protein A - peroxidase conjugate at 7000 times dilution) for an hour at $37^{\circ} \mathrm{C}$. After each step (starting from formalin fixation), plates were washed three times with PBS. Both primary and secondary antibodies were diluted with $1 \%$ BSA in PBS; primary antibodies were diluted starting from 200 times dilution, each step involving a two-fold dilution. Then substrate buffer (10 $\mathrm{ml}$ phosphate-citrate buffer (Sigma, P4809) supplemented with $5 \mathrm{mg}$ o-Phenylenediamine dihydrochloride (Sigma, P6912) and $15 \mu \mathrm{H}_{2} \mathrm{O}_{2}$ ) was added; finally, after incubation in the dark for $30 \mathrm{~min}$ at room temperature in substrate buffer, $1 \mathrm{M} \mathrm{H}_{2} \mathrm{SO}_{4}$ was added to stop the reaction. The optical density was measured at $492 \mathrm{~nm}$ using a Labsystems Multiscan PLUS spectrophotometer. The controls used were incubated cells without primary antibodies and without primary and secondary antibodies.

Cell lysate ELISA. Cells were suspended in cell lysis buffer (CB): $50 \mathrm{mM}$ HEPES-HCl, pH 7.8, $150 \mathrm{mM} \mathrm{NaCl}$, $0.25 \mathrm{M}$ sucrose, $1.5 \mathrm{mM} \mathrm{MgCl}_{2}, 1 \mathrm{mM}$ EDTA, $1 \mathrm{mM}$ DTT, $1 \%$ Triton X100, $1 \mathrm{mM}$ PMSF and $10 \mu \mathrm{l}$ of Protease Inhibitor Cocktail (Sigma, P8340) were added to each $1 \mathrm{ml}$ of suspension. After pulsed ultrasonification (using Micro tip 1 sonotrode; five times the cycle ( 0.7 seconds pulsation followed by 0.3 seconds rest), acoustic power output $135 \mathrm{~W}$, Hielscher, UP200 S) with ice-cooling, the suspension was centrifuged at $6000 \mathrm{rpm}$ for 15 minutes. Pellet wash with a small volume of $\mathrm{CB}$ was joined to the first supernatant and was used for ELISA to check antibodies or was fractionated on a Sepharose 4B column, size $0.6 \times 20 \mathrm{~cm}$ (diameter $\mathrm{x}$ length, respectively). Elution was performed with the PBS buffer $1 \mathrm{ml} / \mathrm{h} /$ fraction.

For sorption on Maxi-sorb plates, cell lysates made from $5 \times 10^{6}$ HepG2 cells in $1.2 \mathrm{ml}$ and from $1 \times 10^{7} \mathrm{H} 9 \mathrm{c} 2$ in 2.4 $\mathrm{ml}$ were diluted 400 times with sodium carbonate coating buffer (in both cases the protein concentration was $15 \mu \mathrm{g} / \mathrm{ml}$ (by UV)). Lysates from CHO, HEK293 and transfected HEK293 cells were also fractionated by gel-filtration. 100 $\mu 1$ of aliquots of fractions were mixed with $12 \mathrm{~g} l$ of $10 \times$ carbonate buffer (18.9 mM NaHCO $3,27.6 \mathrm{mM} \mathrm{Na}_{2} \mathrm{CO}_{3}, \mathrm{pH}$ 9.6) for coating on Maxi-sorb plates. Adsorbed lysates were blocked for $30 \mathrm{~min}$ at $37^{\circ} \mathrm{C}$ with $5 \%$ BSA in PBS; primary and secondary antibodies were diluted with $1 \%$ BSA in PBS.

Western blotting. Chemiluminiscent Western-blot analysis was performed according to the manufacturer's recommendations using Super Signal West Femto Maximum Sensitivity Substrate (Pierce). The result was fixed on Amersham Hyperfilm ECL.

CXCR4-eGFP receptor detection with fluorometer. To quantify the effectiveness of transfection, cells after 24, 48 or 72 hours (after transfection) were washed with PBS and detached by scraping from the growth surface. Subsequently they were counted and their fluorescence measured on a fluorometer VIKTOR 3V (Perkin-Elmer) using an excitation filter $(485 \mathrm{~nm})$ and emission filter $(535 \mathrm{~nm})$. The fluorometer was operated with lamp energy $7112 \mathrm{eV}$. The fluorescence intensity was recorded 1 second. Fluorescence non-transfected cell and PBS measurements were used as background. The fluorescence intensity was normalised to $10^{6}$ cells.

Microscopic detection of the CXCR4-eGFP receptor. In order to determine receptor localisation in cells, cells transfected with plasmid pCEP4-CXCR4-eGFP were fixed with $3.7 \%$ formalin (Sigma, F8775) (diluted in PBS) and stained with wheat germ agglutinin (WGA) conjugated with AlexaFluor 633 (Invitrogen) for cell wall recognition.

Another approach used for receptor detection was cell fixation (with $3.7 \%$ formalin for $5 \mathrm{~min}$ ) and incubation with anti-543 antibodies (dilution determined empirically by titration of antibodies; in this case, $1: 500$ ) for one hour. For visualisation, anti-rabbit secondary antibodies linked with fluorescent TRITC (diluted 700 times) (Sigma, T6778) were subsequently bound to those anti-543 antibodies for one hour.

In both cases, prior to viewing the cells microscopally, they were stained with DAPI for cell nucleus detection. Using a DMI3000 microscope (Leica Microsystems) with filter cubes A, I3 and Y5, the fluorescence of DAPI, eGFP and AlexaFluor633, respectively, was detected.

\section{RESULTS}

The human CXCR4 gene contains two exons of 103- and 1563-bp size interrupted by a 2132-bp intron precisely between codon 5 (AGT/Ser (S)) and codon 6 (ATA, Ile (I)) of the $\mathrm{NH}_{2}$-terminal domain (Wegner et al., 1998). Figure 1 shows the scheme for construction of the desired plasmids. Three primer oligonucleotides, named pARS13, pARS14 and pARS15 were chosen for the cloning experiment.

The upstream primer pARS13 contains the coding sequence for the first sixteen aminoacids of CXCR4 and is complementary towards beginning of the $2^{\text {nd }}$ exon. This primer ensures that the join between the two exons of CXCR4 gene passes over the naturally occurring splicing sequence that corresponds to Ser-Ile and is underlined (Fig. 1, A). Two fully complementary primers pARS14 and pARS15 toward the end of the $2^{\text {nd }}$ exon were used to obtain fragments for the insertion into the corresponding vectors pcDNA3 (Fig. 1, B) and pCEP4 (Fig. 1, C). In that way, two variants were constructed - one gene for the receptor sequence (Fig. 1, $\mathrm{B})$ and one for the receptor C-terminally fused with green fluorescence protein eGFP (Fig. 1, C). The latter allowed us to estimate the level of cell transfection via fluorescence.

Two kinds of antibodies (commercial CXCR4 and anti-543) were tested with cells (Fig. 2, A) and cell lysates (Fig. 2, B); it was shown that the anti-543 antibodies operate well and are sufficiently specific. This result allowed us to use them for Western blot (Fig. 3) analysis. Two specific lines 


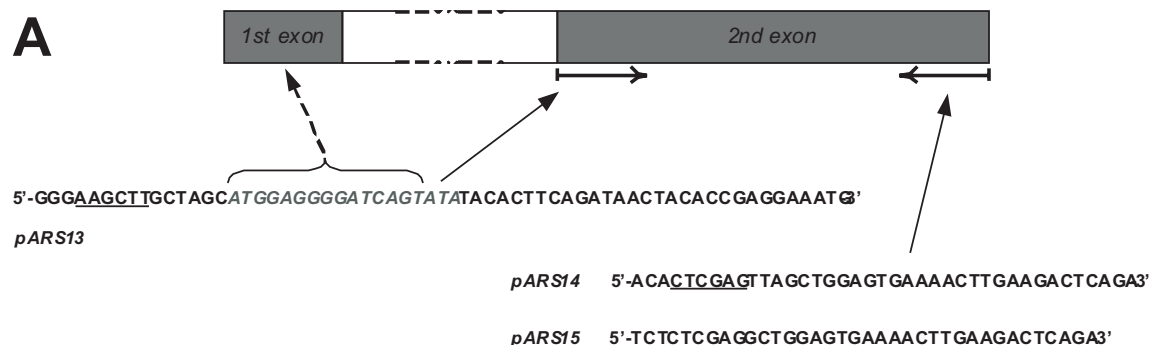

PARS15 5'-TCTCTCGAGGCTGGAGTGAAAACTTGAAGACTCAGA3'
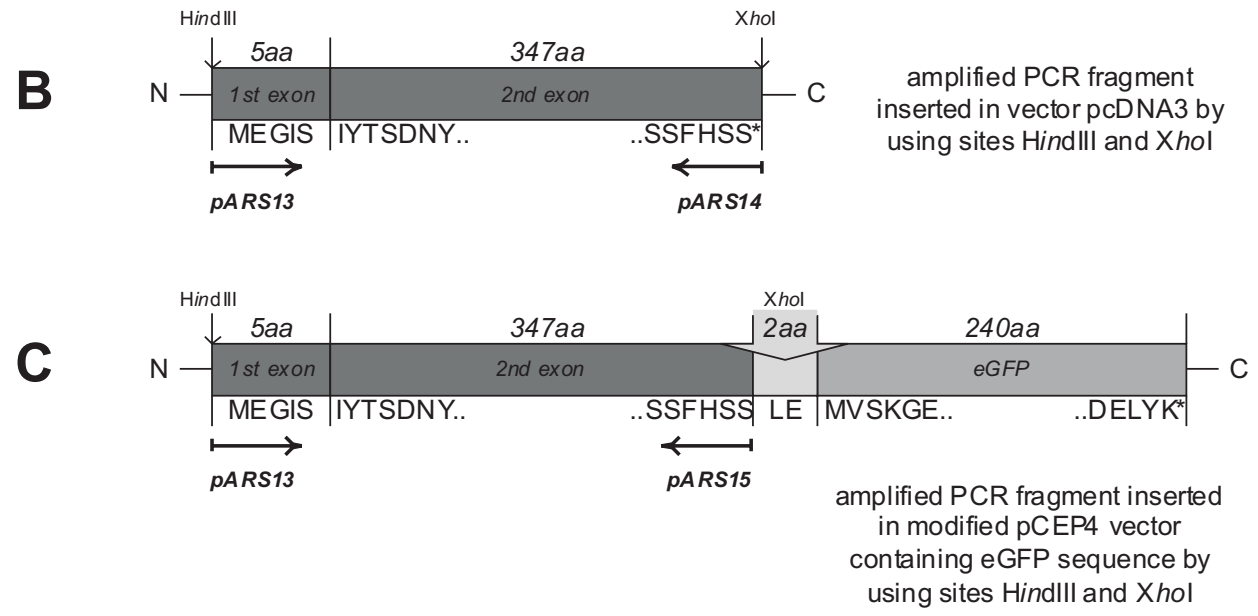

Fig. 1. Cloning scheme of the constructions pcDNA3-CXCR4 and pCEP4-CXCR4-eGFP.

The CXCR4 sequence was obtained from human genome (A) and via HindIII and XhoI restriction sites (underlined) inserted into corresponding vectors (B and C).
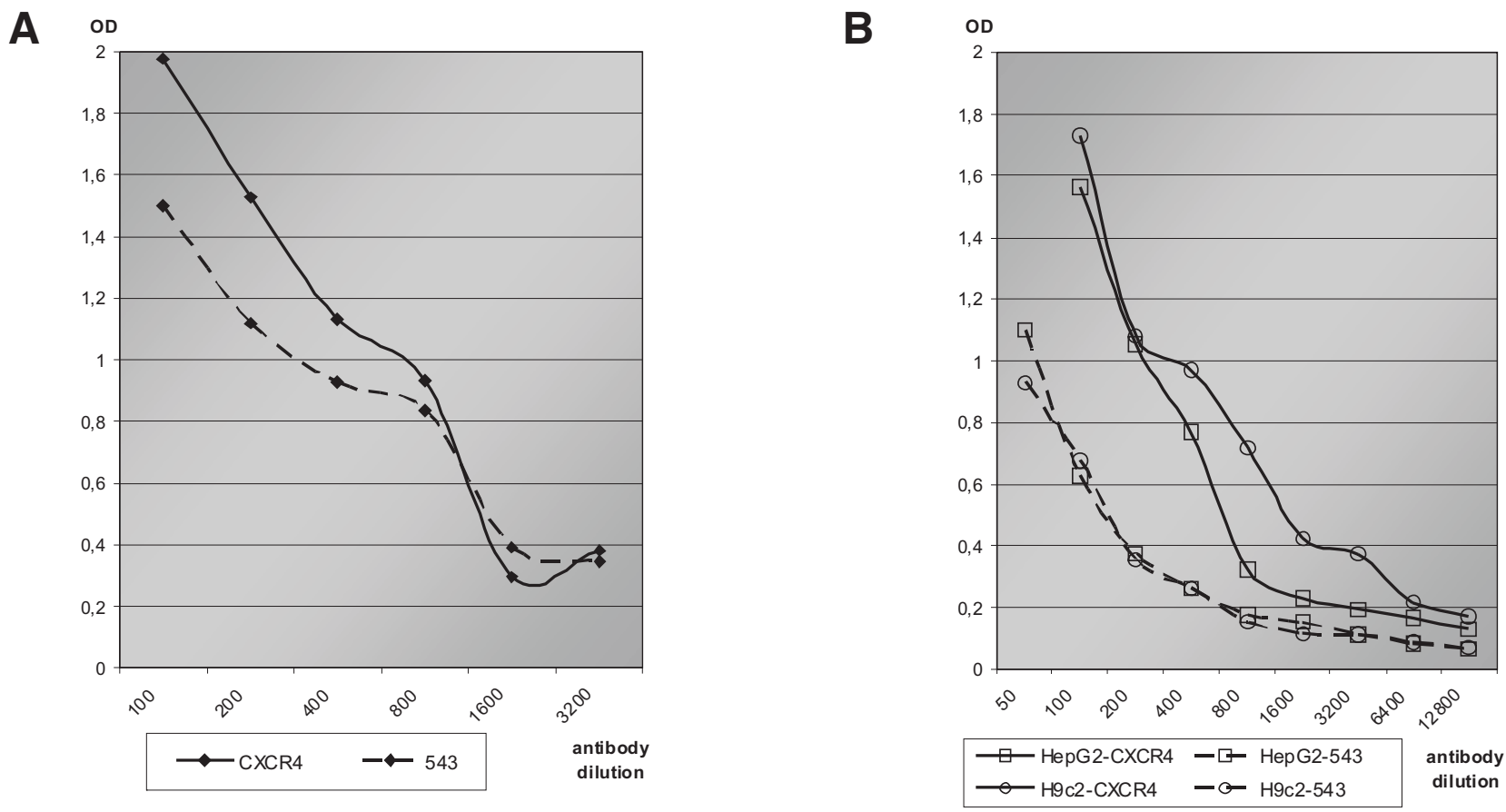

Fig. 2. Two types of ELISA (cell and cell lysate) with anti-CXCR4 and anti-543 antibodies.

A, with pCEP-CXCR4-eGFP transfected HEK293 cell ELISA with anti-CXCR4 and anti-543 antibodies; B, HepG2 and H9c2 cell lysate ELISA with anti-CXCR4 and anti-543 antibodies.

(Fig. 3, A, fractions 6 and 7), one of them minor, with MW close to $60 \mathrm{kDa}$ were clearly visible in the analysis of transfected HEK293 cell lysates. The bulk of the active material remains in the upper part of the Western blot, in particular the fractions of transfected cell lysates. CXCR4 heterogenity and multiplicity are well known (Lapham et al., 2002). The most useful data for judging the effectivity of cell transfection and level of receptor CXCR4 expression were obtained using plasmid pCEP4 (Fig. 1, C). Fusion of the CXCR4 sequence with eGFP allowed to measure the level of expression as GFP fluorescence intensity.

The influence of lipofectin on the cell transfection effectivity is demonstrated in Figure 4. Microscope monitoring 
A

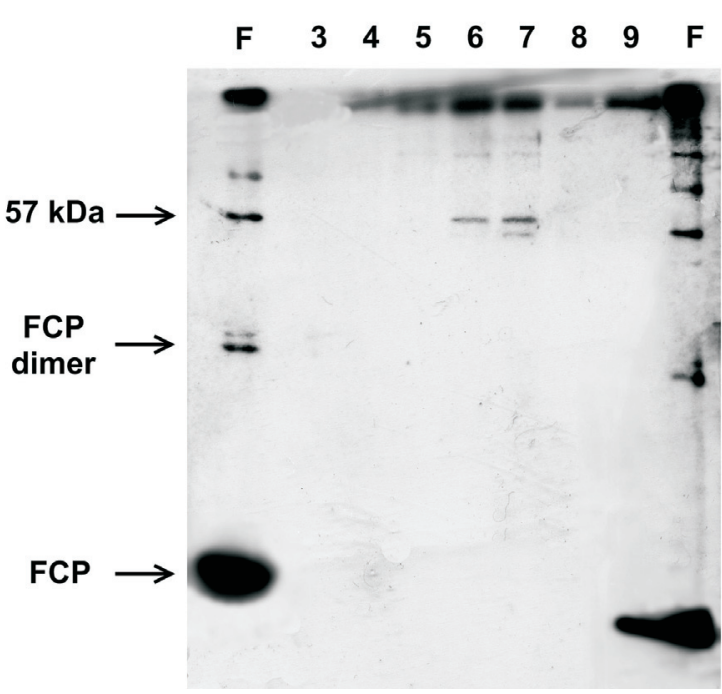

$\mathrm{C}_{3}$

$\begin{array}{llllllllllll}3 & 4 & 5 & 6 & 7 & F & 4 & 5 & 6 & 7 & 8 & D\end{array}$

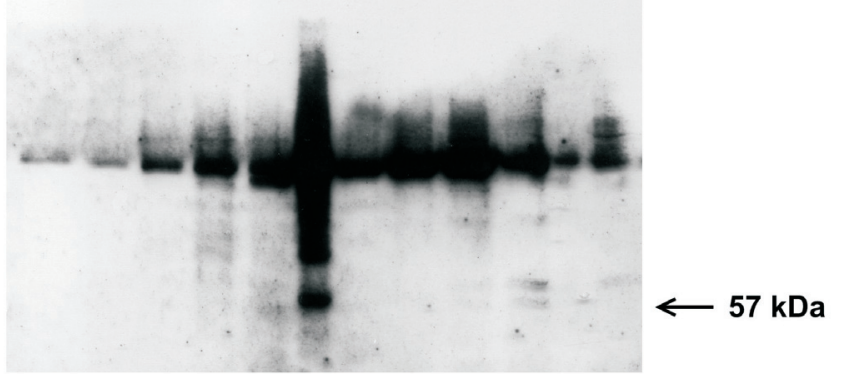

showed that about one tenth of the cells were transfected. The cells expressed their own autofluorescence but dilution resulted in differentiation of the two "fluorescences".

The effectivity of transfection with lipofectin and TurboFect is summarised in Table 1. Transfection is a dynamic process, depending on several factors. Nevertheless, the data

Table 1

FLUORESCENCE MEASUREMENTS FROM DIFFERENT CELL LINES TRANSFECTED WITH PCEP-CXCR4-EGFP PLASMID*

\begin{tabular}{c|c|c|c|c|c}
\hline $\begin{array}{c}\text { Transfectio } \\
\text { n reagent }\end{array}$ & $\begin{array}{c}\text { Growth } \\
\text { time after } \\
\text { transfection }\end{array}$ & $\begin{array}{c}\text { Used } \\
\text { transfection } \\
\text { method }\end{array}$ & BHK21 & CHO & HEK293 \\
\hline Lipofectine & 48 & A & 1272 & - & 17113 \\
& 48 & A & 710 & 1697 & 3194 \\
& 48 & A & 1082 & 9344 & 904 \\
& 48 & B & 1206 & 4829 & 779 \\
& 72 & A & - & 20436 & - \\
\hline TurboFect & 24 & A & 4895 & - & 8672 \\
& 24 & A & - & - & 10212 \\
& 24 & B & 4955 & - & 14105 \\
& 24 & B & - & - & 15184 \\
& 48 & A & 10843 & 10863 & 2764 \\
& 48 & A & 4085 & 9806 & 17260 \\
& 48 & B & 25680 & 19610 & 779 \\
& 48 & B & - & - & 1499
\end{tabular}

*The fluorescence intensity is normalized to $10^{6}$ cells.
B $\quad$ A260

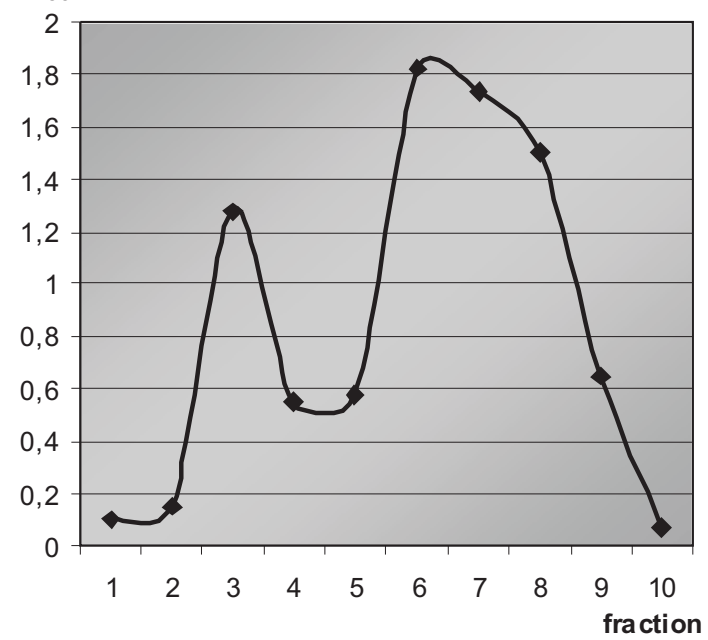

Fig. 3. Sepharose 4B-CL column fractionated HEK293 cell lysate Western blot with anti-543 antibodies. A, Western blot with HEK293 cell lysate after chromatography on Sepharose 4B-CL column and detected with anti-543 antibodies; 3 to 9 are appropriate fractions, $\mathrm{F}$ is the phage used in the antibody manufacturing process; B, HEK293 cell lysate after 4B column chromatography; fractions correspond to the Western blot in Figure 3, A; C, Western blot with anti-543 antibodies, comparing non-transfected and transfected HEK293 cell lysates after Sepharose 4B-CL column; in the left part of gel 3-7 fractions are non-transfected cells, in the right part 4-8 fractions are transfected cells, $\mathrm{F}$ is the phage used in the antibody manufacturing process, and D is transfected cell lysate debris.

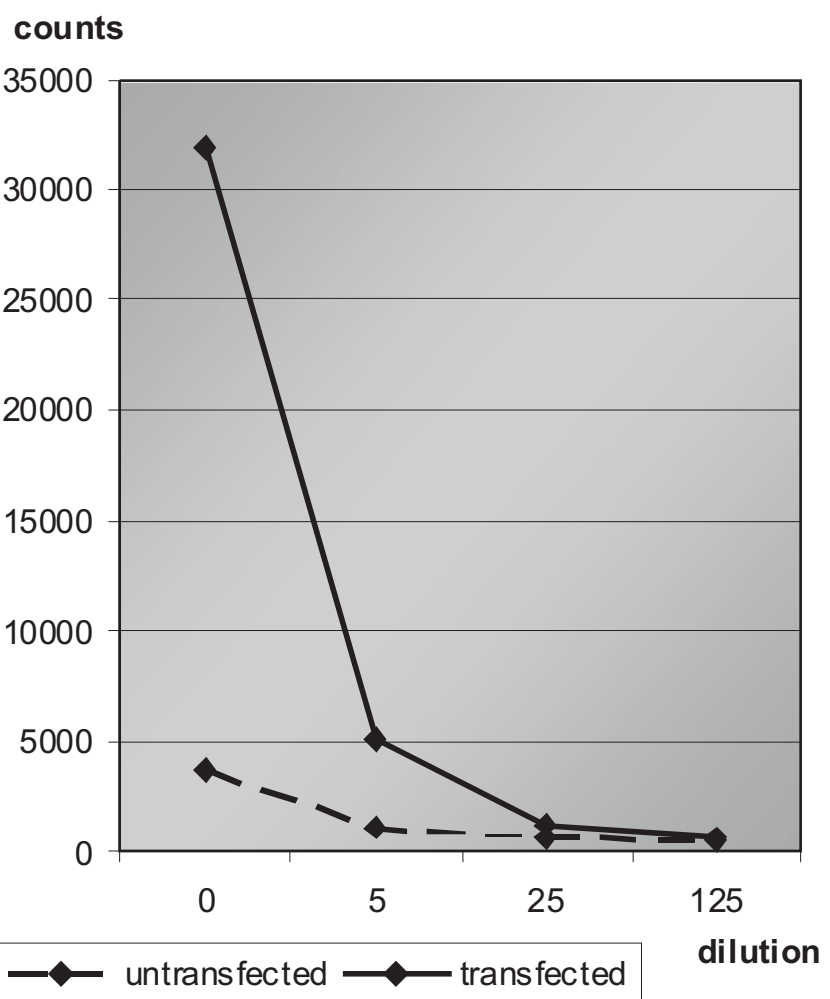

Fig. 4. Fluorescence of HEK293 cells $\left(1 \times 10^{7}\right)$ untransfected or transfected with plasmid pCEP-CXCR4-eGFP (Fig. 1, C); measurements with filter pair $485 \mathrm{~nm} / 535 \mathrm{~nm}$. 

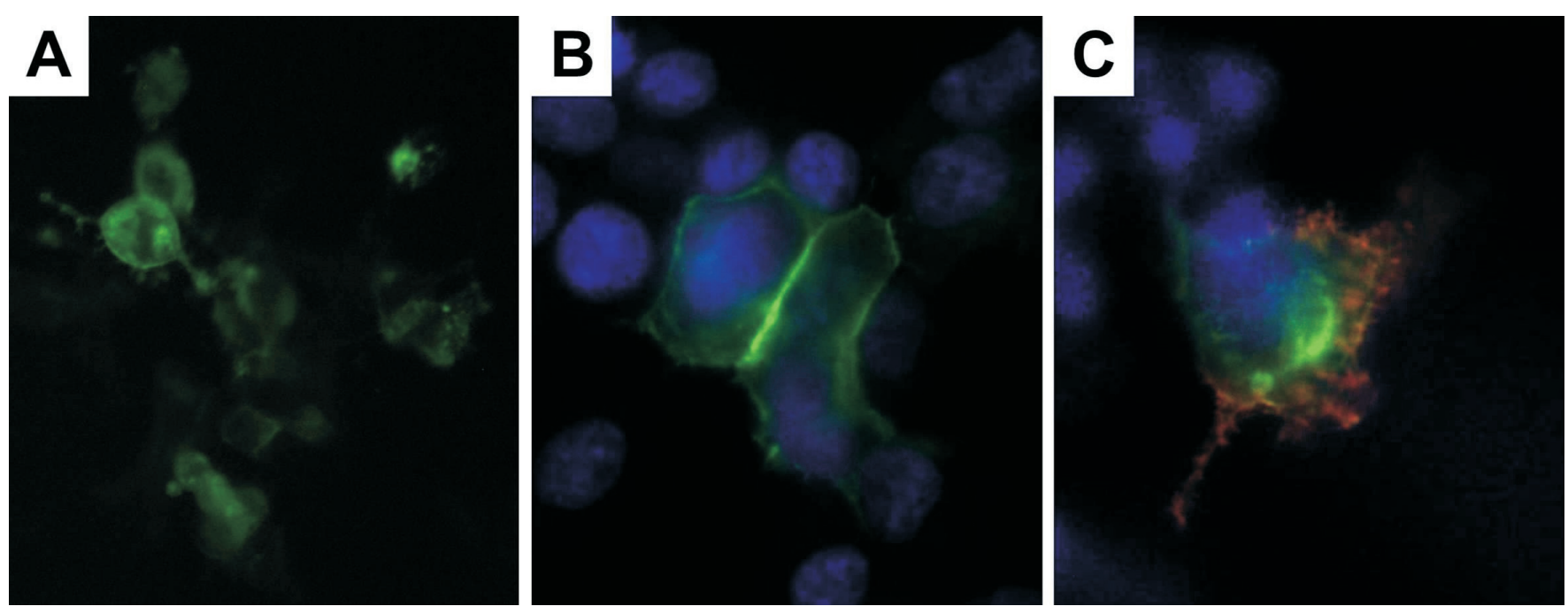

Fig. 5. Fluorescent microscopic images with transfected BHK21 or HEK293 cells, recorded with a Leica DMI3000 microscope using Leica Microsystems filter cubes A, I3 and Y5 for detection of DAPI, eGFP and WGA-Alexa647 fluorescence, respectively. Magnification $400 \times$. A, BHK21 cells transfected with plasmid pCEP-CXCR4-eGFP; B, HEK293 cells transfected with plasmid pCEP-CXCR4-eGFP and stained with DAPI; C, HEK293 cells transfected with plasmid pCEP-CXCR4-eGFP, incubated with 543 antibodies that subsequently conjugated with TRITC-marked secondary anti-rabbit antibodies and stained with DAPI.

show that TurboFect is much more effective in all the cell lines used and gives more stable results. For BHK cells the highest result was observed after 48 hours with medium exchange. Stable and sufficiently high results were achieved for HEK293 in a 24-hour experiment; better results were observed with medium exchange. For these cells prolongation of growth till 48 hours gave a relatively lower yield because of active untransfected cell growth. For CHO the highest transfection yield was observed with lipofectine after 72 hours of growth and with TurboFect after 48 hours with medium exchange. Cells transfected with eGFP construct are shown in Figure 5.

\section{DISCUSSION}

The CXCR4-overexpressing system may serve as an effective tool to study regulation and functionality of this unique receptor and has potential for gene therapy. Predevelopment of a system facilitating constitutive or transient CXCR4 expression on the cell surface will be a first step in studying receptor-ligand interactions, especially if ligand analogues made as virus-like particles become available.

CXCR4 is constitutively expressed by freshly isolated human thymocytes at a level of $\sim 10000$ molecules/cell in about $30 \%$ of thymocytes. In contrast, in another receptor, CCR5, expression in freshly isolated thymocytes was significantly lower: $\sim 4000$ molecules/cell in less than $5 \%$ of the cells and no functional response to receptor agonists observed (Zamarchi et al., 2002).
Experimental cloning of CXCR4 has been repeatedly attempted (Loetscher et al., 1994; Bleul et al., 1996; Heesen et al., 1996; Gupta, Pillarisetti, 1999; Kahn et al., 2004). Cell lines with expressed CXCR4 are also commercially available $^{1}$. Nevertheless there are at least three main reasons for us to perform the molecular cloning of this receptor. First, transfection of cells is often unstable, transient. Second, we need different kinds of transfected eukaryotic cells for research purposes and, third, to develop this technique to enable structural modifications of the receptor, for example, through mutations of specific aminoacids, through the usage of chimeras (Doranz et al., 1999) or its isoforms (Xu et al., 2007), or through C-terminal shortening of the protein chain (Hu et al., 1998). The first known experimental cloning of human CXCR4 was performed in 1994. At that time this receptor was called LESTR (Loetscher et al., 1994). Some years later its only natural ligand - SDF-1 (Bleul et al., 1996) was discovered. This first cloning was done via extraction of a total monocyte RNA, isolation of poly(A)+ RNA and cDNA synthesis. The cDNA fragments obtained were ligated into the commercial mammalian expression vector pcDNAI (Invitrogen). Then E. coli was transformed by electroporation, yielding a monocyte cDNA library of about $4 \times 10^{6}$ clones with an average insert size of approximately $1.4 \mathrm{kbase}$. Selection was performed with a labelled 819-bp DNA fragment, coding for part of the rabbit IL-8 receptor. At that time receptors for interleukin 8 were sufficiently well investigated (Moser et al., 1993), and sequence identity for LESTR and IL-8 was found near to $34 \%$. For the generation of neomycin resistant $\mathrm{CHO}$

\footnotetext{
${ }^{1}$ Multiscreen $^{\mathrm{TM}}$ Stable Cell Line Human Recombinant CXCR4 Receptor. Expression vector containing full-length human CXCR4 cDNA (Genbank Accession Number: NM_003467) with FLAG tag sequence at N-terminus. Multispan. http://www.multispaninc.com/file_dir/C1004-1.pdf

ChemiSCREENTM Human Recombinant CXCR4 Chemokine Receptor Calcium-Optimized Ready-to-Assay Cells. Millipore. http://www.millipore.com/catalogue/item/hts004f

ChemiSCREENTM CXCR4 Calcium-Optimized FLIPR Cell Line. Millipore. http://www.millipore.com/catalogue/item/hts004c

Stable CHO-KI cells expressing CXCR4. ReaMetrix. http://readev.reametrix.com/index.php?option=com_content\&view=article\&id=49\&Itemid=55

CXCR4 Expressing Human Promonocytic U937 Cell Lines. GenWay. http://www.genwaybio.com/images/gw_tds/cell_lines/CXCR4.pdf
} 
transfectants the electroporation method was used. Transient transfection in COS cells were performed by the DEAE-dextran or by an electroporation technique. As a general tool for expression of LESTR the expression vector pSVL (Pharmacia) was used. A different level of expression was observed and interpreted as an expression of LESTR mRNA. A high level was observed in human blood neutrophils, in peripheral blood lymphocytes, in HL-60 cells, but only a low level was detected in Jurkat cells. Among four neuroblastoma cell lines that were analysed, only two were found to be CXCR4 positive: LAN5, a cell line derived from a bone marrow neuroblastoma metastasis, and "classical" CH-SY-5Y cells with an only faint hybridisation signal.

Cloning of the mouse CXCR4 fusion gene was achieved in 1996 when, using degenerate PCR; this gene was cloned from a peritoneal exudate cell cDNA library (Heesen et al., 1996). The amino acid sequence was $91 \%$ identical to the human fusion gene. Twenty-eight of the thirty seven amino acid differences between mouse and human fusion genes are located in the ectodomains, suggesting that the intracytoplasmic components that mediate G-protein binding and signalling are highly conserved. Northern blot analysis showed a message of 2.2 kbases in thymus, spleen, neutrophils and primary astrocyte cultures.

Cloning and expression of a novel human CXCR4 splice variant was performed in 1999 (Gupta et al., 1999). The CXCR4-Lo $\sim 4 \mathrm{kDa}$ cDNA was identical from the SmithKline Beecham cDNA database. It codes an additional, unique 9 amino acid extension of the N-terminal domain. Both, full length CXCR4 and CXCR4-Lo cDNA were subcloned into the $\mathrm{pCR}^{\mathrm{R}} 3.1$ (Invitrogen) eukaryotic expression vector. After electroporation into rat basophil, the level of expression of leukaemia cells was estimated with the specific antibodies 12G5. It was found that both cases revealed similar levels of surface expression of CXCR4 and CXCR4-Lo.

The other method for the overexpression of human CXCR4 into CD34+ cells was based on a lentiviral gene transfer system (Kahn et al., 2004). A human 1.2 kbase cDNA was used to the enhanced green fluorescent protein (eGFP, used as a fluorescent reporter) gene via an internal ribosome entry site. The construct was inserted into a SIN HIV-derived lentiviral vector to transfect 293T cell line. Twenty-four hours after transfection, the viral supernatant was collected and used for transduction of target human hematopoietic stem cells. The authors postulated (Kahn et al., 2004) that gene transfer into human hematopoietic stem cells might be a promising tool in the correction of a wide variety of hematopoietic and genetic disorders. Unexpectedly, they found only a $40 \%$ decrease in cell surface receptor expression compared with a $90 \%$ decrease in control cells after in vitro exposure to high levels of SDF-1. Therefore, the authors suggested overexpression of CXCR4 as a universal system for regulating cell function and development.
Our approach to cloning of CXCR4 could be designated as a classical one. On the one hand, it is a well-known object, while, on the other, for us it was interesting to compare how the two transfection agents (lipofectin and TurboFect) with different kinds of eukaryotic cells worked in our experiments. Thus, the receptor CXCR4 sequence was extracted out of the human genome, and two plasmids for expression of this receptor and its fusion with eGFP were constructed. Two transfection reagents (lipofectin and TurboFect) were applied for three cell lines, changing time of cell growth and method. The optimal conditions for each kind of tested cell were identified.

\section{ACKNOWLEDGEMENTS}

The study was supported by the Latvian State Research programme No. 09-VP-2-1 „Novel drug candidates and bio-correction agents: design, transport forms and activity mechanisms", project VZP -10 "Artificial virus like particles - a novel carrier of active compounds".

A grant (A. Strods) from the EU Structural Fund programme 1.1.2.1.2.; subprogramme "Support for Doctoral Studies at University of Latvia” is acknowledged.

\section{REFERENCES}

Adler, M.W., Geller, E.B., Chen, X., Rogers, T.J. (2006). Viewing chemokines as a third major system of communication in the brain. AAPS J., 7(4), E865-E870.

Almofti, A., Uchida, D., Begum, N.M., Tomizuka, Y., Iga, H., Yoshida, H., Sato, M. (2004). The clinicopathological significance of the expression of CXCR4 protein in oral squamous cell carcinoma. Int. J. Oncol., 25(1), $65-71$.

Bleul, C.C., Farzan, M., Choe, H., Parolin, C., Clark-Lewis, I., Sodroski, J., Springer, T.A. (1996). The lymphocyte chemoattractant SDF-1 is a ligand for LESTR/fusin and blocks HIV-1 entry. Nature, 382, 829-833.

Campbell, M.J. (1995). Lipofection reagents prepared by a simple ethanol injection technique. BioTechniques, 18(6), 1027-1032.

Crump, M., Gong, J., Loetscher, P., Rajarathnam, K., Amara, A., Arenzana-Seisdedos, F., Virelizier, J., Baggiolini, M., Sykes, B., Clark-Lewis, I. (1997). Solution structure and basis for functional activity of stromal cell-derived factor-1; dissociation of CXCR4 activation from binding and inhibition of HIV-1. EMBO Journal, 16(23), 6996-7007.

Darash-Yahana, M., Pikarsky, E., Abramovitch, R., Zeira, E., Pal, B., Karplus, R., Beider, K., Avniel, S., Kasem, S., Galun, E., Peled, A. (2004). Role of high expression levels of CXCR4 in tumor growth, vascularization, and metastasis. FASEB J., 18(11), 1240-1242.

Doranz, B.J., Orsini, M.J., Turner, J.D., Hoffman, T.L., Berson, J.F., Hoxie, J.A., Peiper, S.C., Brass, L.F., Doms, R.W. (1999). Identification of CXCR4 domains that support coreceptor and chemokine receptor functions. J. Virol., 73(4), 2752-2761.

Fujii, N., Nakashima, H., Tamamura, H. (2003). The therapeutic potential of CXCR4 antagonists in the treatment of HIV. Expert Opin. Investig. Drugs, 12(2), 185-195.

Gupta, S.K., Pillarisetti, K. (1999). Cutting edge: CXCR4-Lo: molecular cloning and functional expression of a novel human CXCR4 splice variant. J. Immunol., 163(5), 2368-2372.

Heesen, M., Berman, M.A., Benson, J.D., Gerard, C., Dorf, M.E. (1996). Cloning of the mouse fusin gene, homologue to a human HIV-1 co-factor. J. Immunol., 157(12), 5455-5460. 
Holm, N.T., Byrnes, K., MacDonald, M., Abreo, F., Ampil, F., Sanders, M., Burton, G.V., Li, B., Chu, Q. (2007). Overexpression of chemokine receptor CXCR4 in cancer specimens following neoadjuvant chemotherapy predicts outcome in patients with locally advanced breast cancer (LABC). $J$. Clin. Oncol. (Meeting Abstracts), 25, 10578.

Hu, H., Shioda, T., Hori, T., Moriya, C., Kato, A., Sakai, Y., Matsushima, K., Uchiyama, T., Nagai, Y. (1998). Dissociation of ligand-induced internalization of CXCR-4 from its co-receptor activity for HIV-1 Env-mediated membrane fusion. Arch. Virol., 143(5), 851-861.

Kahn, J., Byk, T., Jansson-Sjostrand, L., Petit, I., Shivtiel, S., Nagler, A., Hardan, I., Deutsch, V., Gazit, Z., Gazit, D., Karlsson, S., Lapidot, T. (2004). Overexpression of CXCR4 on human CD34+ progenitors increases their proliferation, migration, and NOD/SCID repopulation. Blood, 103(8), 2942-2949.

Kalinkovich, A., Tavor, S., Avigdor, A., Kahn, J., Brill, A., Petit, I., Goichberg, P., Tesio, M., Netzer, N., Naparstek, E., Hardan, I., Nagler, A., Resnick, I., Tsimanis, A., Lapidot T. (2006). Functional CXCR4-expressing microparticles and SDF-1 correlate with circulating acute myelogenous leukemia cells. Cancer Res., 66(22), 11013-11020.

Kato, M., Kitayama, J., Kazama, S., Nagawa, H. (2003). Expression pattern of CXC chemokine receptor-4 is correlated with lymph node metastasis in human invasive ductal carcinoma. Breast Cancer Res., 5(5), R144-R150.

Loetscher, M., Geiser, T., O'Reilly, T., Zwahlen, R., Baggiolini, M., Moser, B. (1994). Cloning of a human seven-transmembrane domain receptor, LESTR, that is highly expressed in leukocytes. J. Biol. Chem., 269(1), 232-237.

Moser, B., Barella, L., Mattei, S., Schumacher, C., Boulay, F., Colombo, M. P., Baggiolini, M. (1993). Expression of transcripts for two interleukin 8 receptors in human phagocytes, lymphocytes and melanoma cells. Biochem. J., 294(Pt 1), 285-292.

Murphy, B., Boynton, A. L., Sehgal, A. (2005). United States Patent 6863887. Washington D.C.: U.S. Patent and Trademark Office.

Nagasawa, T., Tachibana K., Kawabata K. (1999). A CXC chemokine SDF-1/PBSF: A ligand for a HIV coreceptor, CXCR4. Adv. Immunol., 71, 211-228.

Schrader, A.J., Lechner, O., Templin, M., Dittmar, K.E., Machtens, S., Mengel, M., Probst-Kepper, M., Franzke, A., Wollensak, T., Gatzlaff, P., Atzpodien, J., Buer, J., Lauber J. (2002). CXCR4/CXCL12 expression and signalling in kidney cancer. Brit. J. Cancer, 86(8), 1250-1256.

Tsutsumi, H., Tanaka, T., Ohashi, N., Masuno, H., Tamamura, H., Hiramatsu, K., Araki, T., Ueda, S., Oishi, S., Fujii, N. (2007). Therapeutic potential of the chemokine receptor CXCR4 antagonists as multifunctional agents. Biopolymers, 88(2), 279-289.

Wegner, S.A., Ehrenberg, P.K., Chang, G., Dayhoff, D.E., Sleeker, A.L., Michael, N.L. (1998). Genomic organization and functional characterization of the chemokine receptor CXCR4, a major entry co-receptor for human immunodeficiency virus type 1. J. Biol. Chem., 273(8), 4754-4760.

Xu, C., Sui, J., Tao, H., Zhu, Q., Marasco, W. A. (2007). Human anti-CXCR4 antibodies undergo $\mathrm{VH}$ replacement, exhibit functional V-region sulfation, and define CXCR4 antigenic heterogeneity. J. Immunol., 179(4), 2408-2418.

Zamarchi, R., Allavena, P., Borsetti, A., Stievano, L., Tosello, V., Marcato, N., Esposito, G., Roni, V., Paganin, C., Bianchi, G., Titti, F., Verani, P., Gerosa, G., Amadori, A. (2002). Expression and functional activity of CXCR-4 and CCR-5 chemokine receptors in human thymocytes. Clin. Exp. Immunol., 127(2), 321-330.

Received 11 September 2009

\section{CXCR4 RECEPTORA KLONĒŠANA UN EKSPRESĒŠANA EIKARIOTISKAJĀS ŠŪNĀS CHO, HEK293 UN BHK21}

Hemokīni un to receptori tiek intensīvi pētīi dažādos aspektos - teorētiski, lai saprastu to darbības principus, un praktiski, lai atklātu metodes, kas ḷautu ietekmēt organismā notiekošos šūnu procesus vai pat vadīt tos vēlamā virzienā. Pēdējo gadu pêtījumi liecina par hemokīnu nozīmīgu lomu normālā šūnu proliferācijā, migrācijā un starpšūnu komunikācijā, bet interesi rada hemokīnu loma daudzos patofizioloğiskos procesos - hroniskos un akūtos iekaisumos, infekcijas slimībās, angioǵenēzes modulācijā un ḷaundabīgo audzēju attīstībā. Hemokīni ir atrasti arī atsevišķos smadzeṇu rajonos, kur ligandu-receptoru sistēma spēj nopietni ietekmēt neironāli aktīvu farmakoloğisko aǵentu darbību. Mūsu interese ir vērsta uz receptora-liganda pāri CXCR4 / CXCL12 (SDF-1). Mēs mēǵinājām pārekspresēt šo receptoru vairākās eikariotisko šūnu līnijās, lai detalizētāk noskaidrotu receptora CXCR4 mijiedarbību ar ligandu - uz vīrusiem līdzīgām dalinnām balstītu analogu, kas satur receptora vienīgā dabiskā liganda SDF-1 (stromālo šūnu faktora) fragmentus. Šis pētījums ir veltīts CXCR4 ekspresēšanai CHO, HEK293 un BHK21 šūnās cerībā izveidot noderīgu ,instrumentu” turpmākajām studijām. 